\title{
Executive Compensation and Tournament Theory: \\ Empirical Tests on Danish Data
}

\author{
Tor Eriksson
}

Working Paper 96-13

November 1996 


\author{
Published by \\ Centre for Labour Market and Social Research \\ Science Park Aarhus \\ Gustav Wieds Vej 10C, 8000 Aarhus C, Denmark
}

Editor: Henning Bunzel

Copyrights:

ISSN 0908-8962 


\title{
Executive Compensation and Tournament Theory: Empirical Tests on Danish Data
}

\author{
Tor Eriksson
}

Working Paper 96-13

November 1996

JEL classifications: J33, J41, M12

Keywords: Tournaments, compensation

\begin{abstract}
This paper adds to the small empirical literature on the theory of tournaments as a theory of executive compensation. We test several propositions of tournament models on a rich data set containing information about 2,600 executives in 210 Danish firms (per year) during a four-year period. The aspects of tournaments analysed are: Are pay differentials between job levels consistent with relative compensation ? Is the pay dispersion between levels higher in noisy environments ? Is the dispersion affected by the number of tournament participants ? Is the average pay lower in firms with more compressed pay structures ? Does wider pay dispersion enhance firm performance ?
\end{abstract}

\section{Acknowledgement}

Earlier versions of this paper were presented at the SOLE meetings in Chicago. The International Conference on Comparative Analysis of Enterprise Data in Helsinki, a Nordic Workshop on Managerial Compensation in Arhus, and the EALE conference in Chania, all in 1996. Helpful comments by George Baker, Martin Conyon, Peter Jensen, Edwar Lazear and Canice Prendergast are gratefully appreciated. Thanks og also to Mette Lausten and Anja Baastrup Nielsen who helped me with portions of the data set.

\section{Addresses}

Tor Eriksson, CLS and Department of Economics, Aarhus School of Business, Fuglesangs Allé 20, DK-8210 Århus V, Denmark, e-mail: TOR@HHA.DK 



\section{Introduction}

Our intention in this paper is to test some predictions that have emerged in the theory of tournaments as a theory of pay structures of firms and to add to the small empirical literature on this subject. Our data base comes from a major Danish consulting firm and contains fairly detailed information about managers, their jobs, their compensation and the firms in which they are employed.

The present study is one of very few in four respects. First, it uses actual data on executives, second, the basis of our analysis is more general as the data are from over 260 firms (and not from a case study of a single firm) and third, it is one of the first investigations of managerial pay structures on data from outside the US. Finally, it attempts to test for several aspects of tournament theory on the same data set, whereas most previous studies, save Main et al. (1993), have examined whether facts square with only one or two predictions for each data set. It should be noted, however, that individually the tests are rather coarse as the alternative hypothesis is not always exactly identified.

We focus on the following aspects of tournaments. Are pay differentials between job levels, controlling for individual and firm characteristics, consistent with relative compensation? Is the prize in the tournament affected by the number of participants? Is the pay dispersion between job levels greater in noisy business environments? Does a wider spread in pay enhance firm performance? Are there differences between firms in this respect? Is the average pay lower in firms with more compressed pay structures?

The paper proceeds as follows. In the next section some basic theoretical notions and earlier work is briefly discussed. The data to be used in the empirical analysis is described in the third section. Two sections of tests follow next. The first is concerned with shape of the pay and job level relationship and the other reports some tests of other aspects of tournaments. In the final section some concluding remarks are offered. 


\section{Theory and existing work}

To illustrate some points let us provide a simple model which follows that set out in Lazear and Rosen (1981). There are two identical players, denoted $\mathrm{j}$ and $\mathrm{k}$, and the game has a fixed prize to the winner, $\mathrm{W}_{1}$, and the loser receives another fixed prize, $\mathrm{W}_{2}$. The winner is the player who produces the largest output. The players' output (performance):

$$
q_{i}=\mu_{i}+\square_{i}
$$

depends on the player's effort level (action), $\mu$, and a random component (as for example luck) denoted by '. The disutility of effort is described by the cost of effort function $\mathrm{C}=\mathrm{C}(\mu)$ and it is assumed that both $\mathrm{C}^{\prime}$ and $\mathrm{C}^{\prime \prime}$ are positive.

The probability that $\mathrm{j}$ wins $\mathrm{W}_{1}$ depends positively on how much effort he puts forth $(\mu)$ and negatively on the actions of the other player $\left(\mu_{\mathrm{k}}\right)$. In addition, the probability of winning is also affected by the distribution of `. The expected utility of the jth player is:

$$
\left.P\left(W_{1}-C\left(\mu_{j}\right)\right)+(1+P)\left(W_{2}-C\left(\mu_{j}\right)\right)=P\left(W_{1}-W_{2}\right)+W_{2}-C\left(\mu_{j}\right)\right)
$$

where $\mathrm{P}$ is the probability of winning.

The probability that $\mathrm{j}$ wins is then:

$$
\begin{aligned}
\operatorname{prob}\left(q_{j}>q_{k}\right) & =\operatorname{prob}\left(\left(\square_{k}-\square\right)<\left(\mu_{j}-\mu_{k}\right)\right. \\
& =\operatorname{prob}\left(\left(\mu_{j}-\mu_{k}\right)>\square\right)=G\left(\mu_{j}-\mu_{k}\right)
\end{aligned}
$$

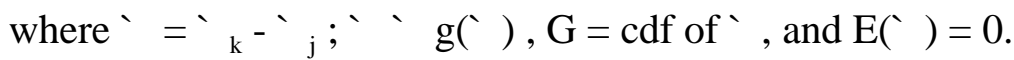

Each of the players maximises (3) by choosing the effort level. The conditions for optimum (assuming an interior solution) are: 


$$
\left(W_{1}-W_{2}\right) \square P / \square \mu_{i}-\square C / \square \mu_{i}=0
$$

and

$$
\left(W_{1}-W_{2}\right) \square^{2} P / \square \mu_{i}^{2}-\square^{2} C / \square \mu_{i}^{2}<0 \quad i=j, k
$$

If both players are maximising (3) taking the other player's action as given, then using (3):

$$
\square P / \square \mu_{j}=\square G\left(\mu_{j}-\mu_{k}\right) / \square \mu_{j}=g\left(\mu_{j}-\mu_{k}\right)
$$

which after substitution into (4) gives player j's best reaction function:

$$
\left(W_{1}-W_{2}\right) g\left(\mu_{j}-\mu_{k}\right)=\square C / \square \mu_{j}
$$

Of course, given the assumption of identical players, both chooses the same effort level and player k's reaction function is symmetric. In Nash equilibrium, $\mu_{\mathrm{j}}=\mu_{\mathrm{k}}$ and the outcome of the game is random (that is, $\mathrm{P}=0.5$ ). Thus,

$$
\left(W_{1}-W_{2}\right) g(0)-\square C_{i} / \square \mu_{i}=0
$$

Given the labour supply characterised by (5), firms maximise profits per worker (which here is equal to the number of job slots). It can easily be seen, see Lazear and Rosen (1981), that the average wage necessary to attract employees to the firm and the optimal wage spread are:

$$
\left(W_{1}+W_{2}\right) / 2=C(\mu)
$$

and

$$
W_{1}-W_{2}=1 / g(0) \text {, respectively }
$$

Equation (5) has two implications. First, the equilibrium level of effort is increasing in the spread between the winning and the loosing prize. The levels of the prizes do not affect effort levels as long as prize differentials are unchanged. In the case where there are several positions within the 
firm, tournament theory predicts, see Rosen (1986) that there will be an increasing ratio of pay as the individuals move up along the corporate ladder. This is because the value of winning is not only the winner's prize at that level, but also includes the value of the possibility to compete for larger prizes at higher levels. As a consequence, there is a convex relationship between pay and organisational level. Note, however, that at the final level is there no further prize to be won and CEOs should, therefore, be given an extra prize. Thus, tournament theory predicts an extraordinarily large pay differential between the CEO and the managers at the level next below.

The second implication of (5), and (7), is that the greater the importance of the random components in output (that is, the smaller $\mathrm{g}(0)$ becomes), the lower is the optimum level of effort for a given spread $\mathrm{W}_{1}-\mathrm{W}_{2}$. Hence, in production environments in which contributions of luck or other random factors to output are important, firms use a larger wage spread in order to offset the effort reducing effect of randomness. As pointed out by Lazear (1995), this incentive role of salaries may be of some importance in comparisons of payment structures across industries or countries.

In the model above, the players do not differ with respect to their abilities. However, if they do, it is no longer necessarily the case that the player who puts forth most effort wins the contest. If players know their own ability as well as that of the other players, the outcome may be a lower level of effort. The less able know they are less likely to win and the able win by their innate ability, see Knoeber and Thurman (1994) for a discussion.

Another simplifying assumption was that the number of players was restricted to two. In fact, the number of players does matter in tournament models. This is because with more players, the probability of winning is smaller and hence, to induce the same amount of effort the winning prize has to be increased.

The model sketched above also abstracts from the fact that senior management of a firm often acts as a team performing highly interdependent work and so, compensation based on individual performance may be inappropriate because it leads to too harsh competition among the members in the management team. As stressed by Lazear (1989), pay compression may dominate 
tournament aspects in so called "hawkish" firms in which the managers are especially good at uncooperative behaviour. To see this, we allow for employees to behave strategically against their rivals by augmenting (1) with a "sabotage" parameter ' ${ }_{i}$ which shows the harm $\mathrm{j}(\mathrm{k})$ can inflict on $\mathrm{k}(\mathrm{j})$ :

$$
q_{j}=\mu_{j}-\square_{k}+\square_{j} \text { and } q_{k}=\mu_{k}-\square_{j}+\square_{k}
$$

As sabotage requires effort the cost of effort function now becomes: $C\left(\mu_{i},{ }_{i}\right)$. Denoting the partials with $\mathrm{C}_{1}$ and $\mathrm{C}_{2}$ (both assumed to be positive) respectively, the first order conditions to the employees' maximization problem are:

$$
\begin{aligned}
& \left(W_{1}-W_{2}\right) \square P / \square \mu_{i}=C_{1}\left(\mu_{i}, \square\right) \\
& \text { and } \\
& \left(W_{1}-W_{2}\right) \square P / \square \square_{i}=C_{2}\left(\mu_{i}, \square\right. \text { ). }
\end{aligned}
$$

From these we can see that for a given wage spread, the effort is lower for players who can sabotage (provided $\mathrm{C}_{12}>0$ ). The first order conditions for the firm's maximization problem in case of absence and presence of strategical behaviour, respectively are:

$$
\begin{aligned}
& \left(1-C_{1}\right) \square \mu / \square W_{1}=0,\left(1-C_{1}\right) \square \mu / \square W_{2}=0 \text {, and } \\
& \left(1-C_{1}\right) \square \mu / \square W_{1}-\left(1+C_{2}\right) \square \square / \square W_{1}=0 \text {, and } \\
& \left(1-C_{1}\right) \square \mu / \square W_{2}-\left(1+C_{2}\right) \square \square / \square W_{2}=0
\end{aligned}
$$

Clearly, as $\mathrm{C}_{2}$ is positive, equilibrium effort is higher in the case when players do not behave strategically against their competitors.

The empirical literature on tournament models is quite small. Strong evidence of tournament notions has above all been obtained from studies of sports, see Ehrenberg and Bognanno (1990), Becker and Huselid (1992), and in controlled experiments, Bull et al. (1987). Studies based on data on actual executives are thin on the ground, simply because data sets containing information 
about several managers per firm are hard to find.

Most of the studies have focused on the convexity of the pay structure. O'Reilly et al. (1988), Leonard (1990) and Main et al. (1993) all using the same data set have shown that differences in compensation between hierarchial levels are consistent with tournament theory. Similar results are obtained by Lambert et al. (1993) and in two detailed studies of the personnel records of a single firm, Lazear (1992) and Baker et al. (1994). In a recent study, Conyon (1995), using a large sample of UK firms also isolates a convex pay and job level relationship.

Additional evidence is somewhat more mixed, however. O'Reilly et al. (1988) find a negative and Main et al. (1993) a positive relationship between the number of tournament participants and pay differentials. Main et al. (1993) also consider the effects of the pay structure on firm performance finding evidence in support of tournaments. Drago and Garvey (1996) examine the effects of pay spread on the cooperative behaviour of employees in a multi-task setting. They find strong evidence of a tournament structure; strong promotion incentives were associated with reduced helping efforts and increased individual efforts. Knoeber and Thurman (1994) study the performance of broiler producers facing a tournament compensation structure. Their tests of predictions concerning the effects of prize level and prize differentials, the effects of ability and the existence of handicap systems, all provide strong evidence in favour of tournament theory.

\section{Data description}

The bulk of the data used in this paper comes from an unbalanced panel containing information about approximately 2.600 managers in about 210 Danish firms (per year) during the four-year period 1992-95. The data have been obtained from confidential files of a major Danish consulting firm and provide in addition to annual compensation data, fairly detailed information about the individual characteristics of managers, their jobs and the firms in which they are employed.

The compensation variable includes salary and bonus components as well as the employers' contributions to pension funds (all three are available as separate variables). A relatively small proportion - 20 to 25 per cent of all managers and a third of the CEOs - are paid bonuses and/or 
tantiemes and their average share of total compensation varies between 10 and 12 per cent during the four-year period. Stock options, deferred compensation (except contributions to pensions) and stock awards are not included. This omission is not likely to affect our results much as all three forms of compensation are rare among Danish managers.

The renumeration data set has been augmented with further information on the firms regarding their performance (accounting profits, sales) in the eight-year period 1987-94. This information has been derived from an annual handbook of all Danish firms with an annual turnover exceeding 40 million Danish kroner in 1994 prices or more than 50 employees, called Greens - Børsens håndbog om dansk erhvervsliv.

Three distinguishing features of Danish firms are worth pointing out here. Firstly, most Danish firms are relatively small. To some extent that is simply a natural consequence of the small size of the country and its population. However, the average size of firms in Denmark is small also relative to the other Nordic countries and in particular the large Danish firms are much smaller than those in Finland, Norway and Sweden. Secondly, the corporate governance system is generally of the Nordic-German type, in which mangers are monitored by representatives of banks, large shareholders and closely related firms. Thus, it differs in particular from the Northern American system which is characterised by boards made up mainly of "outsiders" representing the shareholders. Thirdly, several Danish firms are closely held and are not publicly traded. Consequently there is only a relatively small number of firms in the stock market. This applies also to the firms in our data set. ${ }^{1}$

The majority of the firms in our data set are medium-sized or large firms (in the Danish sense) and the data are, therefore, not representative of all Danish firms. However, the sample at our disposal is fairly representative of the medium-sized and large firms with respect to distribution across industries and geographical location.

\footnotetext{
${ }^{1}$ It should be noted, however, that the firms in the sample are not headed by owner-managers.
} 


\section{Pay and job levels}

The first of the tests we carry out concerns the shape of the pay and organisational level relationship. We test for whether differentials in pay between levels (defined in alternative ways) in corporate hierarchies are consistent with tournament models. To obtain estimates of the pay differences between adjacent organisational levels we estimate compensation equations, both from single years and from a short panel (which allows us to account for fixed effects), of the following form:

$$
W_{i j t}=\square_{i}+\square X_{i j t}+\square L_{i j t}+\square_{i j t}
$$

where $\mathrm{W}$ is the logarithm of annual compensation, ' ${ }_{\mathrm{i}}$ individual fixed effects, $\mathrm{X}$ is a vector of individual and firm characteristics, and $\mathrm{L}$ is a vector of job level dummies. $\mathrm{X}$ includes age, tenure in current position, educational level, industry, number of employees, number of subordinates and (log of) sales (and year dummies in panel estimations). L will be defined in three alternative ways; see below. Thus, the `estimates are derived from a model which controls for individual traits (and individual specific fixed effects) as well as some firm characteristics. This may be important as some part of the inter-level pay differences may reflect differences in these characteristics.

It is not self-evident how to define job levels in hierarchies. The data at our disposal contain information about jobs according to their function (production, sales, logistics, personnel etc.), formal position (CEO, VP, higher level manager ("fagdirektør") and lower level manager ("fagchef")) as reported by the firm, membership in the board or the top-management group, and responsibility level (see below). In none of these descriptions are job levels identified according to the pay connected to them.

In order to check the sensitivity of the results to the job level definition adopted, we have used three alternative sets of levels (or positions) in the corporate hierarchy variables. The most detailed description, which however is available only for a portion of the whole sample, is a 
classification of positions into nine levels according to a job authorities evaluation system created by the consulting firm. The classification is based on grades ( 1 to 6$)$ given to six factors: complexity of the problems to be solved, independency in decision making, reporting, responsibility, experience and training requirements.

The second classification is a cruder version of the first one ${ }^{2}$ and classifies the positions held into five different responsibility levels. ${ }^{3}$ All jobs in the sample are covered by this classification. The third set of level dummies has been constructed from two pieces of information: the titles of positions as reported by the firms and board or top-management group membership. This gives us six levels: CEO, VP, a board member higher level manager, a non-board member higher level manager, a board or top-level group member lower level manager and a non-member lower level manager. This classification is also available for all observations in the sample. In the main text below we only discuss the results from using the third classification with six position levels. The estimates from using the other two classifications were quite similar, however, and are set out in the appendix, tables A-1 and A-2.

We begin by looking at the basic data on pay. The average pay (base salary plus bonus) ${ }^{4}$ for each level and the proportional pay differences between adjacent levels, starting from the lowest are presented in Table 1. The figures are from 1994 but the corresponding figures from the other three years are very similar. Irrespective of which one of the levels classifications we have used, the same pattern emerges. As one moves up the corporate hierarchy, the pay differences increase. ${ }^{5}$ Clearly, these simple averages look quite consistent with a tournament structure of

\footnotetext{
${ }^{2}$ The two lowest levels in the cruder classification correspond largely to levels 1 to 4 in the more detailed classification, levels 3 and 4 to 5 and 6 , and level 5 to levels 7 to 9 .

${ }^{3}$ The jobs are classified into three main responsibility levels: the tactical level, the strategical level and the policy level, which is the highest one. For the two lowest responsibility levels a further distinction is made on the basis of whether the position involves making propositions or decisions. Thus, for instance a position at the lower strategical level involves making propositions regarding principal strategies and plans for the firm whereas a person in the position at the higher strategical level has the authority to make those decisions.

4 The results presented are all based on the broadest compensation variable which includes bonuses and tantiemes. The picture remains largely unaltered when we look at base salary only.

5 However, there is one odd feature. For some reason, the rather small group of higher level managers who are neither board members nor members of top management groups in the firms earn more than their colleagues who are members of these bodies. (This unexpected result is found for each year in the sample).
} 
pay. So, let us turn to consider whether this also remains to be the case when we control for individual and firm characteristics.

In Tables 2 and 3 the estimates from equation (7) are shown. The coefficients are those of level dummies in estimations in which the dependent variable, total pay, is in logs and the (omitted) reference category is the lowest job level in the data set. In Table 2 the estimates of job level pay differences by year are presented. As in some previous studies (see e.g. Leonard (1990), Lazear (1992) and Baker et al. (1994)), job levels turn out be a very important determinant of pay. Adding the job level dummies to a specification with standard human capital variables, industry dummies and firm characteristics significantly improves the explanatory power of the model. As can be seen from the table, the pay differences are relatively stable across years.

The estimates can be used to calculate the increase in reward from moving from one level to the next holding individual traits and firm characteristics constant. Thus, from the results for $1995^{6}$ in Table 2, we find that increases in rewards, beginning from the lowest level, are: 13.3, 36.6, 9.5, 14.8, 24.6 and 37.1 per cent. The corresponding figures from Table 3 are: 10.6, 31.6, -4.7, 15.6, 14.5, and 37.2 per cent. The last figure is an estimate of the change in reward of moving from a vice president to CEO position.

A comparison of these figures with those in Table 1 shows that in general controlling for individual and firm characteristics gives rise to a slight reduction in the pay differences between job levels. A further decrease occurs as we cater for heterogeneities (like differences in ability discussed above) by an individual fixed effects specification. The results set out in Table 3 confirm this (see also table A-3 in the appendix for fixed effects estimates on a responsibility specification). The changes are rather small, however, and do not change the qualitative picture observed earlier.

\footnotetext{
${ }^{6}$ Again, the results from the other years were quite similar. Note also that the decrease in rewards between the third and the fourth level may be due to relatively few observations for the group of higher level managers who are neither board nor top management group members.
} 
The key result of the econometric exercises is that the pay difference increases as one moves up in the hierarchy. This increase in spread at higher levels in the hierarchies is consistent with tournament theory. However, we have not been able to isolate an extraordinarily large increase in the reward at the very top of the hierarchy as suggested by rank-order tournament models.

To summarise, the convexity of the relationship between pay and levels in hierarchy documented above is consistent with the operation of tournaments based on relative performance. It also fits well in with the results of an earlier study using the same data, Eriksson and Lausten (1996), which found only a very weak pay for performance relationship. It may well be that executive pay has little to do with the absolute performance of the CEO or other senior managers and that instead the increasing pay differences act as an incentive to provide greater effort.

Although a widening pay gap through the corporate hierarchy is a key prediction of tournament models, the pattern observed does not imply tournament theory as other, economic, see Rosen (1992), as well as sociological theories, see O'Reilly et al. (1988) also predict a convex pay and job level relationship. Thus, for example, provided superiors' decisions affect directly the productivity of lower-level employee, sorting of more able persons into higher level positions will lead to higher marginal productivity of people at higher levels.

Of course, our data description gives no evidence regarding the other key prediction of tournament models, the efficiency of the pay structure. We do not know whether the pay differences are large enough to give rise to incentive effects as suggested by tournament theory.

\section{Other aspects of tournament theory}

Our aim in this section is to try to test some other aspects of tournament theory than the shape of pay-job level relationship. We analyse two types of aspects. Firstly, we investigate whether inter-firm differences in pay dispersion are affected by the factors suggested by tournament models. Are reward differences affected by the number of tournament participants? Are pay differences between job levels higher in noisy or risky environments? Is average pay lower in 
firm with more compressed pay structures? Secondly, we carry out a simple test of the prediction that a wider pay dispersion enhances the economic performance of firms.

In investigating these aspects of tournament models, our unit of observations are firms. The sample analysed below consists of those firms for which we have observations on minimum five employees (one of which is the CEO), complete records on firm performance for the period 1987-94 and on managerial compensation for all four years 1992-95. These restrictions reduces the sample to 111 firms.

McLaughlin (1988) suggests as a test of the presence of tournaments testing for the existence of a positive relationship between CEO pay and (given the average pay of the tournament participants) the number of contestants. Of course, in order to carry such a test, the participants in the tournament have to be identified. One obvious candidate group is the vice presidents. However, as many of the companies in the data set do not have formal VP positions, we have, following O'Reilly et al. (1988), decided to use the managers which are reported by the firms to have significant responsibilities, that is, the managers whose jobs are classified as being at the policy level, as the group of contestants. The dependent variable is the log difference between the CEO pay and the average pay of the other tournament participants.

The results from estimations on data for 1992 and 1994 are presented in Table 4 (see also Table 5, below). The estimates do suggest that, controlling for firm size, a greater number of contestants increases the winning prize, as predicted by tournament models. The magnitude of the effect is rather modest, however.

As was shown in Section 2, a prediction emanating from tournament models is a larger spread in pay in firms operating in noisy or risky environments to compensate for the relatively greater importance of random factors. Consequently, we expect firms in industries where demand or cost conditions vary a lot to have a steeper pay-job level hierarchy.

The main problem with attempting to test this hypothesis is, of course, to find a variable that accurately captures differences in firms' (industries') demand or cost conditions. We have used 
two alternative pieces of information. The data set provides information about the sales of the firms in the period 1987 to 1994 . From these series we have for each firm calculated the coefficient of variation of (deflated) sales. ${ }^{7}$ These coefficients of variation is our first proxy measure of a noisy environment. The other measure is derived in a similar fashion, but now we make use of industry level information. Coefficients of variation were calculated from the Industrial Statistics for the 1987-1993 period for volume of production for each of the two-digit level industries the firms in the sample are operating in. ${ }^{8}$ We tried two alternative dependent variables: the coefficient of variation of total pay and the CEO-contestants differential constructed for the test above. A drawback of the coefficient of variation variable is that it may be affected by differences in the number of managerial positions in firms.

According to the estimation results set out in Table 5, there is indeed a positive and statistically significant relationship between the variability of the sales (production) of the firm (industry) and the intra-firm pay dispersion. Naturally, in interpreting the results it should be kept in mind that the coefficient of variance measure can at best only be crude proxy for a noisy or risky business environment. In particular, they may not capture intra-firm differences in the internal risk of the firms.

The results of the two tests we have carried out so far clearly provide some additional support for the notion of rank-order tournaments. The reward differences are larger the more important are random factors for the development of the performance of the firm and the more competitors are participating in the tournament. However, the above analysis has been concerned with what things look like, and not whether they also work. So, let us now turn to consider the consequences of the pay structure on firm performance.

As is plain from the equilibrium in (5), the wider the pay dispersion, the higher the level of effort put forth. However, as discussed by Lazear (1989), (1995), there may also be incentive motives

\footnotetext{
${ }^{7}$ The firms which have had changes in sales due to acquisitions of other firms or sales of the parts of the firm had to be discarded.

${ }^{8}$ Some firms operate in several industries. We have assigned them to the industries reported by themselves as their main industry.
} 
for firms to adopt a more compressed pay structure. In order to attract (the right) people to participate in a tournament, the spread cannot be "too big". Moreover, if the cooperation of the managers is essential for the succes of the firm, rewarding them according to their individual achievements may not be a good idea. Not all firms benefit from their top managers acting as a team, however. ${ }^{9}$ For those firms, for which cooperation is less important - "hawkish" firms in Lazear's terminology - wider pay gaps may enhance performance, whereas this is not the case in "dovish" firms. Clearly, the main difficulty in testing the hypothesis of the performance enhancing effects of pay dispersion is finding a variable or indicator which enables us to distinguish between "hawkish" and "dovish" firms. We follow Main et al. (1993) in using an executive team interdependency indicator, constructed as the proportion of profit center heads of the total number of managers, which is interacted with our measures of pay dispersion.

As was pointed out earlier, most of the firms in the data set are not publicly held. Hence we cannot rely on stock market indicators as measures of firm performance but use accounting profits information instead. The performance of the firms is measured as a three-year average of profits divided by sales. ${ }^{10}$ Once again, we use two alternative pay dispersion measures for which we calculate four-year averages. Additional explanatory variables included were firm size (measured by the four-year average of the number of employees), industry dummies, and the average pay of the managers in the firm.

What do we find? First of all we find a weak positive relationship between firm performance and average pay. As for the pay dispersion variables, these also attach positive coefficients; a significant one for the CEO-contestants difference and an almost significant one for the coefficient of variation variable. The team interdependency variable as well as the interaction terms never differed significantly from zero. Thus, the industrial politics argument for pay

\footnotetext{
${ }^{9}$ As pointed out by Lazear (1995), an alternative to pay compression as a means of reducing anti-cooperative behaviour of managers is to set up the structure of the firm in such a way that the consequences of competitive behaviour to the firm are minimised.

${ }^{10}$ We have also tried two alternative performance measures. The first was the rate of return on the firm's own capital as reported by Greens. Unfortunately this has one major draw-back, namely that the firm's own capital is measured end-of-year. The estimates obtained were similar as those in Table 6, but they were less precisely estimated. The other measure used was a crude index based on the performance of profits during the eight year period 1987-94. Again, the results were quite similar to those reported above.
} 
compression in managerial teams is not supported by the analysis.

Regressions of the average log of pay on pay dispersion controlling for firm size and industry, show, consistent with tournament theory, a lower average pay in firms with less pay dispersion; see Table 6. But again, we failed to find a significant coefficient for the interdependency variable and the interaction term. It should be noted, that although we have drawn two blanks on these variables, there is considerable scope for improving the analysis, in particular by accounting for differences in the organisational structure of the firms.

\section{Concluding remarks}

In this paper we have investigated some aspects of tournament theory using a data set on Danish executives. We find that there is a stable convex relation between pay and job levels and that this is relatively robust with respect to differences in how job levels are defined. The larger the number of managers considered to have significant responsibilities in the firm, the larger is the wage spread. Thus, the prediction of tournament models that there is a positive relationship between the number of participants in and the prize of the tournament is supported. Another prediction gaining support is a larger pay dispersion in firms characterised by more variable business conditions.

As for the consequences of the pay structure, we find some evidence of a larger spread being associated with better performance of firms. There does not seem to be any differences with regard to the effects of pay dispersion on firm performance between firms the managerial teams of which are more interdependent and those in which they are not. However, it must be noted, that these results are tentative as they may be affected by the problems of measuring accurately the interdependency of managers and/or firm performance.

We may, in summary, conclude that the findings do provide some positive evidence of tournament models. This is important in view of the weak link observed between firm performance and individual managers' pay. 
Table 1. Mean pay (base salary plus bonus) by levels in corporate hierarchy

Level/Position

$\mathrm{N} \quad$ Total pay $\quad$ Difference (\%)

Lower level manager,

no membership

Lower level manager,

board or top-level group

Higher level manager,

no membership

Higher level manager,

top-level group

Higher level manager,

board member

Vice president

CEO

$729 \quad 483.1$

$\begin{array}{lll}714 & 524.9 & +12.4\end{array}$

$90 \quad 844.8 \quad(+60.9)$

$311 \quad 728.6 \quad(-13.7)$

$160 \quad 835.1+14.6$

$\begin{array}{lll}64 & 903.1 & +8.1\end{array}$

$\begin{array}{lll} & 180 & 1.250 .0 \quad+38.4\end{array}$

Table 2. Estimated pay differences (log-differentials)

(standard errors in parentheses)

Position*:

1992

1993

1994

1995

Lower level manager, board or

0.121

(0.012)

top-level group

0.399

(0.023)

0.324

(0.014)

0.489

(0.021)

0.648

(0.021)

0.989

(0.022)

$\mathrm{R}^{2}$ (adj.)

0.699

2289
0.103

(0.011)

0.413

(0.024)

0.319

(0.015)

0.464

(0.019)

0.629

(0.020)

0.951

(0.022)

0.724

2248
0.110

(0.011)

0.420

(0.024)

0.340

(0.014)

0.480

(0.020)

0.620

(0.020)

1.031

(0.025)

0.719

2502
0.125

(0.010)

0.437

(0.025)

0.337

(0.016)

0.475

(0.018)

0.695

(0.021)

1.011

(0.026)

0.701

*. Omitted category: lower level manager with no membership. Other regressors included were: age, tenure in current position, level of education, industry, number of employees in the firm, the number of subordinates, and log of sales. 
Table 3. Fixed effects estimation results

Positions

Lower level manager

0.101

board/top member

$(0.010)$

Higher level manager,

0.375

no membership

Higher level manager,

0.327

top-level group

$(0.015)$

Higher level manager,

0.472

board member

$(0.020)$

Vice president

0.607

$(0.030)$

CEO

0.923

$(0.020)$

$\mathrm{R}^{2}$ (adj.)

0.774

Hausman's test $\left({ }^{-2}(2)\right)$

7.25

N. of obs.

9150

Table 4. Test of the effect of the number of contestants

Dependent variable: log CEO pay - average log managerial pay

1992

1994

\begin{tabular}{|c|c|c|}
\hline Constant & $\begin{array}{c}0.175 \\
(0.039)\end{array}$ & $\begin{array}{l}0.187 \\
(0.052)\end{array}$ \\
\hline $\begin{array}{l}\text { Number of con- } \\
\text { testants }\end{array}$ & $\begin{array}{c}0.018 \\
(0.006)\end{array}$ & $\begin{array}{l}0.017 \\
(0.005)\end{array}$ \\
\hline Firm size (log sales) & $\begin{array}{l}0.0002 \\
(0.0001)\end{array}$ & $\begin{array}{l}0.0002 \\
(0.0001)\end{array}$ \\
\hline$R^{2}$ (adj.) & 0.102 & 0.097 \\
\hline
\end{tabular}


Table 5. Test of the effect of noisy business environment on spread of pay

$\begin{array}{lll}\text { Dependent variable: } & \text { CV of pay } & \text { CEO-Contestants } \\ & (1994) & \text { difference }(1994)\end{array}$

$\begin{array}{lllll}\text { Constant } & 0.311 & 0.295 & 0.122 & 0.111 \\ & (0.054) & (0.059) & (0.034) & (0.033)\end{array}$

Firm size (log

sales)

$0.0002 \quad 0.0002$

$(0.0001) \quad(0.0001)$

CV of firm sales $\quad 0.011$

0.014

(0.005)

$(0.008)$

CV of industry

0.015

0.016

output

(0.003)

(0.005)

Number of con-

$0.015 \quad 0.012$

testants

(0.008) (0.004)

$\mathrm{R}^{2}$ (adj.)

0.064

0.072

0.121

0.134 
Table 6. Tests of effects of pay spread on firm performance and average pay

Dependent variable: Log Profits/sales Log of average pay

$\begin{array}{lclll}\text { Constant } & 3.092 & 3.151 & 6.420 & 6.398 \\ & (0.54) & (0.57) & (0.391) & (0.362) \\ \text { Number of employees } & & & 0.0004 & 0.0004 \\ & & & (0.0002) & (0.0003) \\ \text { Log average pay } & 0.031 & 0.032 & & \\ & (0.011) & (0.010) & 0.392 & \\ \text { CV of pay } & 0.241 & & (0.200) & \\ & (0.145) & & & 0.204 \\ \text { CEO-contestants } & & 0.151 & 0.111 & 0.125 \\ \text { difference } & 0.051 & 0.039 & (0.407) & (0.750) \\ \text { Interdependency } & (0.060) & (0.064) & 0.113 & 0.179 \\ \text { indicator } & -0.005 & 0.010 & (0.222) & (0.451) \\ \text { Interaction (inter- } & (0.015) & (0.020) & & \\ \text { dependency and pay } & & & 0.648 & 0.662 \\ \text { spread) } & & & & \\ \mathrm{R}^{2}(\text { adj.) } & 0.313 & 0.345 & & \\ & & & & \end{array}$

\section{References}

Baker, G., M. Gibbs \& B. Holmström, 1994. The Internal Economics of the Firm: Evidence from Personnel Data, Quarterly Journal of Economics (109), 881-919.

Becker, B. \& M. Huselid, 1992. The Incentive Effects of Tournament Compensation Systems, Administrative Science Quarterly (37), 336-350

Bull, C., A. Schotter \& K. Weigelt, 1987. Tournaments and Piece Rates: An Experimental Study, Journal of Political Economy (95), 1-33

Conyon, M., 1995. An Empirical Test of Tournament Theory Using Data on UK Executives. Mimeo; University of Warwick.

Drago, R. \& G. Garvey, 1996. Incentives for Helping on the Job: Theory and Evidence, forthc. in Journal of Labor Economics.

Ehrenberg, R. \& M. Bognanno, 1990. The Incentive Effects of Tournaments Revisited: 
Evidence from the European PGA Tour, Industrial and Labor Relations Review (43), 7488

Eriksson, T. \& M. Lausten, 1996. Mangerial Pay and Firm Performance - Danish Evidence. Mimeo, Aarhus School of Business

Knoeber, C. \& W. Thurman, 1994. Testing the Theory of Tournaments: An Empirical Analysis of Broiler Production", Journal of Labor Economics (12), 155-179

Lambert, R., D. Larcker \& K. Weigelt, 1993. The Structure of Organizational Incentives, Administrative Science Quarterly (38), 438-461

Lazear, E., 1989. Pay Equality and Industrial Politics, Journal of Political Economy (97), 561580

Lazear, E., 1992. The Job as A Concept, in: William Burns (ed.): Performance Measurement, Evaluation, and Incentives. Harvard Business School Press, Boston

Lazear, E., 1995. Personnel Economics. MIT Press; Cambridge Mass.

Lazear, E. \& S. Rosen, 1981. Rank-order Tournaments as Optimum Labor Contracts, Journal of Political Economy (89), 841-864

Leonard, J., 1990. Executive Pay and Firm Performance, Industrial and Labor Relations Review (43), 13-29

Main, B., C. O’Reilly III \& J. Wade, 1993. Top Executive Pay: Tournament or Teamwork?, Journal of Labor Economics (11), 606-628

McLaughlin, K., 1988. Aspects of Tournament Models: A Survey in: Ronald Ehrenberg (ed.): Research in Labor Economics Vol. 9, 225-256

O’Reilly III, C., B. Main \& G. Crystal, 1988. CEO Compensation as Tournament and Social Comparison: A Tale of Two Theories, Administrative Science Quarterly (33), 257-274

Rosen, S., 1986. Prizes and Incentives in Elimination Tournaments, American Economic Review (76), 701-715

Rosen, S., 1992. Contracts and the Market for Executives in: Lars Werin and Hans Wijkander (eds.): Contract Economics. Basil-Blackwell, Oxford 


\section{Appendix}

Table A-1. Mean pay (base salary plus bonus) by levels in corporate hierarchy, alternative job level definitions

A. Responsibility levels

Level N Total pay Difference* $(\%)$

Tactic level, lower

$\begin{array}{rcr}821 & 455.0 & \\ 723 & 574.1 & +26.2 \\ 476 & 796.6 & +38.8 \\ 183 & 1.110 .9 & +39.5 \\ 45 & 1.679 .7 & +51.2\end{array}$

* Proportional difference $\mathrm{w} \mathrm{r} \mathrm{t}$ next lowest level

B. More detailed responsibility levels

\begin{tabular}{lrcc} 
Level & $\mathrm{N}$ & Total pay & Difference $(\%)$ \\
\hline 1 & 21 & 407.3 & \\
2 & 55 & 443.5 & +8.9 \\
3 & 103 & 499.9 & +12.7 \\
4 & 39 & 591.2 & +18.3 \\
5 & 51 & 678.4 & +14.7 \\
6 & 34 & 834.0 & +22.9 \\
7 & 26 & 870.2 & +4.3 \\
8 & 16 & 1.065 .7 & +22.5 \\
9 & 16 & 1.377 .9 & +29.3 \\
\hline
\end{tabular}


Table A-2. Estimated pay differences (log-differentials), alternative job level definitions (standard errors in parentheses)

A. Responsibility levels

\begin{tabular}{lcclc} 
& 1992 & 1993 & 1994 & 1995 \\
\hline Tactic level, higher* & 0.227 & 0.188 & 0.189 & 0.161 \\
& $(0.009)$ & $(0.010)$ & $(0.009)$ & $(0.009)$ \\
Strategic level, lower & 0.517 & 0.458 & 0.473 & 0.442 \\
& $(0.009)$ & $(0.012)$ & $(0.011)$ & $(0.011)$ \\
Strategic level, higher & 0.842 & 0.758 & 0.885 & 0.707 \\
& $(0.013)$ & $(0.018)$ & $(0.016)$ & $(0.025)$ \\
Policy level & 1.234 & 1.074 & 1.205 & 1.607 \\
& $(0.024)$ & $(0.031)$ & $(0.029)$ & $(0.171)$ \\
$\mathrm{R}^{2}$ (adj.) & 0.688 & 0.700 & 0.727 & 0.711 \\
N. of obs. & 2289 & 2248 & 2502 & 2111 \\
& & & & \\
\hline
\end{tabular}

* Omitted category: tactic level, lower

B. A more detailed classification of responsibility levels

\begin{tabular}{lllll} 
Level*: & 1992 & 1993 & 1994 & 1995 \\
\hline & & & & \\
\hline & & & & \\
3 & 0.030 & 0.044 & 0.049 & 0.095 \\
& $(0.041)$ & $(0.050)$ & $(0.039)$ & $(0.030)$ \\
4 & 0.139 & 0.129 & 0.155 & 0.202 \\
& $(0.040)$ & $(0.051)$ & $(0.038)$ & $(0.030)$ \\
5 & 0.307 & 0.228 & 0.278 & 0.309 \\
& $(0.042)$ & $(0.054)$ & $(0.044)$ & $(0.034)$ \\
6 & 0.453 & 0.393 & 0.395 & 0.500 \\
& $(0.045)$ & $(0.057)$ & $(0.043)$ & $(0.038)$ \\
7 & 0.554 & 0.482 & 0.572 & 0.573 \\
& $(0.049)$ & $(0.060)$ & $(0.046)$ & $(0.040)$ \\
8 & 0.572 & 0.475 & 0.594 & 0.549 \\
& $(0.056)$ & $(0.068)$ & $(0.050)$ & $(0.046)$ \\
9 & 0.689 & 0.619 & 0.859 & 0.865 \\
& $(0.077)$ & $(0.100)$ & $(0.053)$ & $(0.135)$ \\
& 0.844 & 0.738 & 1.076 & 1.043 \\
$\mathrm{R}^{2}$ (adj.) & $(0.109)$ & $(0.128)$ & $(0.065)$ & $(0.190)$ \\
$\mathrm{N}$. of obs. & & & & \\
& 0.654 & 0.666 & 0.698 & 0.655 \\
& 341 & 288 & 336 & 335
\end{tabular}

* Omitted category: the lowest level 
Table A-3. Fixed effects estimation results; responsibility levels

Responsibility levels

Tactic, higher

0.174

$(0.009)$

Strategic, lower

0.464

$(0.010)$

Strategic, higher

0.721

$(0.017)$

Policy level

1.210

$(0.090)$

$\mathrm{R}^{2}$ (adj.)

0.766

Hausman's test ( ' $2(2)$ )

6.98

N. of obs.

9150 
Working

Paper

95-01 Christian Belzil: Contiguous Duration Dependence and Nonstationarity in Job Search

95-02 Christian Belzil: Unemployment Insurance and Unemployment Over Time: An Analysis with Event History Data.

95-03 Christian Belzil: Unemployment Duration Stigma and Reemployment Earnings.

95-04 Christian Belzil: Relative Efficiencies and Comparative Advantages in Job Search.

95-05 Niels Henning Bjørn: Causes and Consequences of Persistent Unemployment.

95-06 Nicholas M. Kiefer and Mark F.J. Steel: Bayesian Analysis of the Prototypal Search Model.

95-07 Nicholas M. Kiefer, Ranjini Natarajan and Charles E. McCulloch: Maximum Likelihood for the Multinomial Probit Model.

95-08 Christian Belzil and Philip Hergel: Fertility and the Human Capital Loss of Non-Participation

95-09 Christian Belzil, William A. Sims and Philip Hergel: Endogeneity, Self-Selectivity and the Sensitivity of Female Earnings to Non-Participation.

95-10 Paul Bingley, Niels Henning Bjørn and Niels Westergård-Nielsen: Wage Mobility in Denmark 1980-1990.

95-11 Audra J. Bowlus, Nicholas M. Kiefer and George R Neumann: Estimation of Equilibrium Wage Distributions with Heterogeneity.

95-12 Anders Björklund and Tor Eriksson: Unemployment and Mental Health: Evidence from Research in the Nordic Countries 
Working

Paper

95-13 Melvyn G. Coles and John G. Treble: Here Today, Gone Tomorrow: Calculating the Price of Worker Reliability.

95-14 Christian Belzil: Employment Reallocation, the Return to Human Capital and the Allocation of Workers Between Expanding and Declining Firms.

95-15 John T. Addison and Jean-Luc Grosso: Job Security Provisions and Employment: Revised Estimates.

95-16 John T. Addison and McKinley L. Blackburn: A Puzzling Aspect of the Effect of Advance Notice on Unemployment.

95-17 Peder J. Pedersen and Nina Smith: The Welfare State and the Labour Market.

95-18 Mette Lausten: Inter-Industry Wage Differentials in Denmark ?

96-01 Mark Yuying An: Log-concave Probability Distributions: Theory and Statistical Testing.

96-02 Audra Bowlus, Nicholas M. Kiefer and George R. Neumann: Fitting Equilibrium Search Models to Labour Market Data.

96-03 Karsten Albæk, Mahmood Arai, Rita Asplund, Erling Barth and Erik Strøyer Madsen: Employer Size-Wage Effects in the Nordic Countries.

96-04 Bent J. Christensen and Nicholas M. Kiefer: Inference in Non-Linear Panels with Partially Missing Observations: The Case of the Equilibrium Search Model.

96-05 Michèle Naur and Nina Smith: Cohort Effects on the Gender Wage Gap in Denmark.

96-06 Elizabeth J. Cunningham: The Relationship between Recruiting and Screening within the Employer Search Framework

96-07 Tim Barmby and Nina Smith: Household Labour Supply in Britain and Denmark: Some Interpretations Using a Model of Pareto Optimal Behaviour.

96-08 Michael Rosholm: Unemployment Duration over the Business Cycle.

96-09 Mark Yuying An and Ming Liu: Structural Analysis of Labor Market Transitions Using Indirect Inference 
Working

Paper

96-10 Paul Bingley and Niels Westergård-Nielsen: Worker and Plant Wages: Estimates from a Multi-Level Model

96-11 Paul Bingley and Gauthier Lanot: Danish Private Sector Wage Policies and Male Retirement Decisions

96-12 George R. Neumann and Gauthier Lanot: Measuring Productivity Differences in Equilibrium Search Models.

96-13 Tor Eriksson: Executive Compensation and Tournament Theory: Empirical Tests on Danish Data.

96-14 Peter Jensen and Helena Skyt Nielsen: Child Labour or School Attendance ? Evidence from Zambia.

96-15 Ebbe Krogh Graversen: Male and Female Labour Supply in Denmark.

96-16 Tor Eriksson and Markus Jäntti: The Distribution of Earnings in Finland 19711990.

96-17 Ebbe Krogh Graversen: Measuring Labour Supply Responses to Tax Changes by Use of Exogenous Tax Reforms.

97-01 Report $1993-1996$.

97-02 Paul Bingley and Ian Walker: Labour Supply with In-Work and In-Kind Trans fers.

97-03 Paul Bingley and Ian Walker: Household Unemployment and the Labour Supply of Married Women.

97-04 Christian Belzil: Job Creation and Destruction, Worker Reallocation and Wages.

97-05 Christian Belzil: The Dynamics of Female Time Allocation upon a First Birth

97-06 Christian Belzil and Jörgen Hansen: Estimating the Returns to Education from a Non-Stationary Dynamic Programming Model

97-07 Niels Westergård-Nielsen and Anders Rue Rasmussen: Apprenticeship Training in Denmark - the impacts of subsidies. 
97-08 H. Bunzel, B.J. Christensen, P. Jensen, N.M. Kiefer, L. Korsholm, L. Muus, G.R. Neumann, M. Rosholm: Specification and Estimation of Equilibrium Search Models.

97-09 Ebbe Krogh Graversen: Work disincentive effects of taxes among Danish married men and women

97-10 Jukka Vittaniemi: Top Executive Compensation and Company Performance in Finland.

97-11 Peder J. Pedersen and Nina Smith: Trends in the Danish Income Distribution, 1976-90.

97-12 Ronald L. Oaxaca and Michael R. Ransom: Identification in Detailed Wage Decompositions

97-13 Bent J. Christensen and Nicholas M. Kiefer: Panel Data, Local Cuts and Orthogeodesic Models

97-14 Michael Rosholm: The risk of marginalization in the labour market: Application of a three state dependent competing risks duration model.

97-15 Helena Skyt Nielsen and Michael Rosholm: The Incidence of Unemployment: Identifying Quits and Layoffs

97-16 Tor Eriksson: Long-Term Earnings Mobility of Low-Paid Workers

97-17 Lars Korsholm: The Semiparametric Normal Variance-Mean Mixture Model

98-01 Helena Skyt Nielsen: Two Notes on Discrimination and Decomposition

98-02 Esben Agerbo, Tor Eriksson, Preben Bo Mortensen and Niels Westergård-Nielsen: Unemployment and mental disorders - an empirical analysis

98-03 Birthe Larsen: Minimum Wages, Technological Progress and Loss of Skill

98-04 Kevin T. Reilly and Tony S. Wirjanto: Does More Mean Less ? The Male/Female Wage Gap and the Proportion of Females at the Establishment Level 
ISSN 0908-8962

\section{CENTRE FOR LABOUR MARKET AND SOCIAL RESEARCH} Science Park Aarhus, Gustav Wieds Vej 10C, 8000 Aarhus C, Denmark Phone: +458942 $2350 \quad$ Fax: +4589422365Ｅmail: cls@cls.dkＷWW: http://www.cls.dk 